\title{
Substituent effects on the genotoxicity of 4-nitrostilbene derivatives
}

\author{
B.H. Hooberman, M.D. Brezzell, S.K. Das, Z. You, J.E. Sinsheimer * \\ College of Pharmacy, University of Michigan, Ann Arbor, MI 48109-1065, USA
}

Received 27 September 1993; revision received 30 June 1994; accepted 13 July 1994

\begin{abstract}
4-Nitrostilbene and twelve of its derivatives (eleven E-stilbenes and two Z-stilbenes) were examined for possible quantitative structure-activity relationships of their in vitro and in vivo genotoxicity. Relative mutagenicity was studied with and without S9 activation in Salmonella strains TA98 and TA100, as well as in the nitroreductase deficient strains TA98/NR and TA100/NR. Chromosomal aberrations in the bone-marrow cells of mice following intraperitoneal administration of the nitrostilbenes were observed as an indicator of in vivo genotoxicity. All of the compounds were active in TA98 and TA100 without S9 activation, with the exception of 4-amino-4'-nitrostilbene in TA100. Mutagenic activity was greatly reduced or eliminated in the NR strains, which is consistent with metabolic activation of the compounds by bacterial reductase. The presence of S9 lowered the activity of most of the nitrostilbenes presumedly by enzymatic detoxication. Hammet values of substituents, partition coefficients and frontier orbital energies $\left(E_{\mathrm{LUMO}}\right.$ and $E_{\text {HOMO }}$ ) were studied for correlations with mutagenicity of the eleven E-stilbenes. Correlations could be established between mutagenicity in TA98 without S9 activation and the Hammet values. The same mutagenicity could also be correlated to $E_{\mathrm{LUMO}}$. Rationales for these correlations include the concept that electron-withdrawing groups which lower $E_{\text {LUMO }}$ should facilitate the reduction of the nitro group, leading to the proximate mutagen hydroxylamine. The correlations are also explained by the concept that electron-withdrawing groups should help stabilize the hydroxylamine intermediate and make the ultimate mutagenic species, the nitrenium ions, more reactive toward DNA. The relationship between mutagenicity and electronic effects of substituent groups found in vitro could not be extended to the in vivo results. However, except for the dinitrostilbenes, where insolubility prevented their testing, all the nitrostilbenes produced a statistically significant increase in chromosomal aberrations compared to the negative solvent control.
\end{abstract}

Keywords: Nitrostilbene; Salmonella mutagenicity; Chromosomal aberration, bone-marrow, in vivo; Quantitative structure-activity relationship; Substituent electronic effect; Partition coefficient; Frontier orbital energy

\footnotetext{
* Corresponding author.
} 


\section{Introduction}

The established mutagenicity, genotoxicity and animal carcinogenicity of nitroaromatic compounds (Rosenkranz and Mermelstein, 1983; 1985; Rickert, 1985; Tokiwa and Ohnishi, 1986) together with their importance as chemical intermediates (Harter, 1985) and their presence as environmental contaminants (Rosenkranz and Mermelstein, 1985; Tokiwa and Ohnishi, 1986) have made these compounds of considerable concern as genotoxic pollutants. While much of the toxicology research in this connection has dealt with nitrated polycyclic aromatic hydrocarbons, Mullin et al. (1987) have established the mutagenicity of a series of conjugated $p$-nitrophenyl derivatives in which 4-nitrostilbene had the greatest mutagenicity in their set of compounds.

It is our objective to examine the possible quantitative structure-activity relationships (QSAR) in the genotoxicity of a series of $3^{\prime}$ and $4^{\prime}$-substituted derivatives of 4-nitrostilbene,

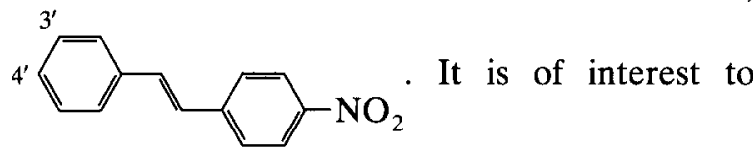

compare these QSAR results to those developed by Hansch and coworkers (Debnath et al., 1991, 1992b) as well as to the studies of Vance et al. (1987, 1988) for nitroaromatic compounds. The 4-nitrostilbene derivatives examined in the present report were employed as intermediates for the synthesis of the corresponding 4-aminostilbene compounds that were the subject of our recent QSAR study of their genotoxicity (You et al., 1994). This presents the opportunity to not only compare the genotoxicity of the nitro compounds within their own series but to relate this to their amino derivatives. Both stilbene series may share a common proximate mutagen prior to nitrenium ion formation in that the nitro compounds may be reduced to a hydroxylamine and the aminostilbenes could undergo oxidation to the same intermediate (Beland and Kadlubar, 1990).

The test system employed for these comparisons was the Salmonella mutagenicity assay, with and without $\mathbf{S} 9$ activation, using strains TA98 and TA100 as well as their nitroreductase deficient variants, TA98/NR and TA100/NR. In addition, preliminary in vivo testing was undertaken by examining bone-marrow cells for chromosomal aberrations (CA) following intraperitoneal (ip) administration of the 4-nitrostilbenes to mice.

\section{Materials and methods}

\section{Chemicals}

4,4'-Dinitrostilbene was synthesized by the Wittig reaction between (4-nitrobenzyl)triphenylphosphonium bromide and 4-nitrobenzaldehyde as previously described (Sinsheimer et al., 1992). In this procedure, except as noted for the Z-isomers of the cyanostilbenes, the reaction mixture from the Wittig procedure was treated with iodine in refluxing ethyl acetate to isomerize any Z-isomer so as to isolate only the E-isomers. In the following summaries of the Wittig reactions with the appropriate benzaldehydes, the NMR data were obtained at $300 \mathrm{MHz}$ with deuterated chloroform as the solvent.

3,4'-Dinitrostilbene was synthesized from 3nitrobenzaldehyde using the procedure for $4,4^{\prime}$ dinitrostilbene, and purified by recrystallization from methanol/ethyl acetate to give yellow needles (83\%): $\mathrm{mp} 220-221^{\circ} \mathrm{C}$ (Weast and Grasselli, 1989: $\left.220-222^{\circ} \mathrm{C}\right)$. NMR $7.300(2 \mathrm{H}, \mathrm{s}), 7.591(1 \mathrm{H}$, $\mathrm{dd}, J=8.0,7.9 \mathrm{~Hz}), 7.691(2 \mathrm{H}, \mathrm{d}, J=8.9 \mathrm{~Hz})$, 7.850 (1II, ddd, $J=7.9,1.6,1.0 \mathrm{~Hz}$ ), $8.185(1 \mathrm{H}$, ddd, $J=8.0,2.2,1.0 \mathrm{~Hz}), 8.270(2 \mathrm{H}, \mathrm{d}, J=8.9$ $\mathrm{Hz}), 8.430(1 \mathrm{H}, \mathrm{dd}, J=2.2,1.6 \mathrm{~Hz})$.

4-Nitrostilbene was prepared in a similar manner from benzaldehyde and purified by recrystallization from methanol/water to yield yellow needles (73\%): $\mathrm{mp} 156-157^{\circ} \mathrm{C}$ (Weast and Grasselli, 1989: $\left.156-157^{\circ} \mathrm{C}\right)$. NMR $8.229(2 \mathrm{H}, \mathrm{d}, J=8.8$ $\mathrm{Hz}), 7.642(2 \mathrm{H}, \mathrm{d}, J=8.8 \mathrm{~Hz}), 7.560(2 \mathrm{H}, \mathrm{dd}$, $J=8.2,1.1 \mathrm{~Hz}), 7.44-7.32(3 \mathrm{H}, \mathrm{m}), 7.28(1 \mathrm{H}, \mathrm{d}$, $J=16.3 \mathrm{~Hz}), 7.15(1 \mathrm{H}, \mathrm{d}, J=16.3 \mathrm{~Hz})$.

The Z-derivatives, (Z)-3-cyano-4'-nitrostilbene and (Z)-4-cyano-4'-nitrostilbene were obtained from 3-cyanobenzaldehyde and 4-cyanobenzaldehyde respectively. The crude products without isomerization were recrystallized from ethanol to yield the following results. 
(Z)-3-Cyano-4'-nitrostilbene (40\%): $\mathrm{mp}$ 97$98^{\circ} \mathrm{C} . \mathrm{C}_{15} \mathrm{H}_{10} \mathrm{~N}_{2} \mathrm{O}_{2}$ Calcd C $71.99, \mathrm{H} 4.03, \mathrm{~N}$ 11.19; found C 71.59, H 3.99, N 10.90. NMR $8.110(2 \mathrm{H}, \mathrm{d}, J=8.9 \mathrm{~Hz}), 7.542(1 \mathrm{H}, \mathrm{dt}, J=7.4$, $1.7 \mathrm{~Hz}), 7.494(1 \mathrm{H}$, br s), 7.42-7.32 (2H, m), 7.324 $(2 \mathrm{H}, \mathrm{d}, J=8.9 \mathrm{~Hz}), 6.764(2 \mathrm{H}, \mathrm{s})$.

(Z)-4-Cyano-4'-nitrostilbene (35\%): $\mathrm{mp} 168-$ $170^{\circ} \mathrm{C} . \mathrm{C}_{15} \mathrm{H}_{10} \mathrm{~N}_{2} \mathrm{O}_{2}$ Calcd C 71.99, $\mathrm{H} \mathrm{4.03,} \mathrm{N}$ 11.19; found $\mathrm{C} 71.69, \mathrm{H} 3.90, \mathrm{~N}$ 10.91. NMR $8.114(2 \mathrm{H}, \mathrm{d}, J=8.9 \mathrm{~Hz}), 7.546(2 \mathrm{H}, \mathrm{d}, J=8.5$ $\mathrm{Hz}), 7.336(2 \mathrm{H}, \mathrm{d}, J=8.9 \mathrm{~Hz}), 7.285(2 \mathrm{H}, \mathrm{d}$ $J=8.5 \mathrm{~Hz}), 6.789(2 \mathrm{H}, \mathrm{s})$.

The corresponding E-isomers, on the other hand, were derived from the Wittig condensation product, which was filtered through a layer of silica gel with ethyl acetate to remove polar impurities and then subjected to isomerization. Recrystallization from ethanol then gave the data below.

3-Cyano-4'-nitrostilbene (76\%): $\mathrm{mp} 161-163^{\circ} \mathrm{C}$. $\mathrm{C}_{15} \mathrm{H}_{10} \mathrm{~N}_{2} \mathrm{O}_{2}$ Calcd C 71.99, H 4.03, N 11.19; found $\mathrm{C} 71.78, \mathrm{H} \mathrm{4.03}, \mathrm{N} 10.84$. NMR $8.253(2 \mathrm{H}$, $\mathrm{d}, J=8.9 \mathrm{~Hz}), 7.828(1 \mathrm{H}, \mathrm{t}, J=1.4 \mathrm{~Hz}), 7.765$ $(1 \mathrm{H}, \mathrm{dt}, J=7.9,1.4 \mathrm{~Hz}), 7.660(2 \mathrm{H}, \mathrm{d}, J=8.9$ $\mathrm{Hz}), 7.611(1 \mathrm{H}, \mathrm{dt}, J=7.9,1.4 \mathrm{~Hz}), 7.515(1 \mathrm{H}, \mathrm{t}$, $J=7.9 \mathrm{~Hz}), 7.213(2 \mathrm{H}, \mathrm{s})$.

4-Cyano-4'-nitrostilbene (70\%): $\mathrm{mp} 258-260^{\circ} \mathrm{C}$ (Veschamber and Kergomard, 1966: $259-261^{\circ} \mathrm{C}$ ). NMR $8.255(2 \mathrm{H}, \mathrm{d}, J=8.9 \mathrm{~Hz}), 7.685(2 \mathrm{H}, \mathrm{d}$, $J=8.2 \mathrm{~Hz}), 7.672(2 \mathrm{H}, \mathrm{d}, J=8.9 \mathrm{~Hz}), 7.635(2 \mathrm{H}$, $\mathrm{d}, J=8.2 \mathrm{~Hz}), 7.252(2 \mathrm{H}, \mathrm{s})$.

For the following compounds the Wittig condensation reaction mixture was poured into water and extracted with diethyl ether. The ether extracts were condensed and filtered through silica gel to remove polar impurities. The resulting crude product was then subjected to isomerization.

3-Chloro-4'-nitrostilbene was obtained from 3chlorobenzaldehyde and purified by recrystallization from methanol to afford yellow-green crystals (64\%): $\mathrm{mp} 118-119^{\circ} \mathrm{C}$ (Veschamber and Kergomard, 1966: $\left.118-118.5^{\circ} \mathrm{C}\right)$. NMR $8.233(2 \mathrm{H}$, d, $J=8.9 \mathrm{~Hz}), 7.636(2 \mathrm{H}, \mathrm{d}, J=8.9 \mathrm{~Hz}), 7.544(1 \mathrm{H}$, br s), $7.411(1 \mathrm{H}, \mathrm{dt}, J=6.7,1.7 \mathrm{~Hz}), 7.36-7.27$ $(2 \mathrm{H}, \mathrm{m}), 7.200(1 \mathrm{H}, \mathrm{d}, J=16.5 \mathrm{~Hz}), 7.139(1 \mathrm{H}$, d, $J=16.5 \mathrm{~Hz}$ ).

4-Chloro-4'-nitrostilbene was prepared similarly from 4-chlorobenzaldehyde and also recrystallized from methanol to yield yellow needles (70\%): $\mathrm{mp} 185-187^{\circ} \mathrm{C}$ (Schiemenz and Thobe (1966): $\left.180-182^{\circ} \mathrm{C}\right)$. NMR $8.227(2 \mathrm{H}, \mathrm{d}, J=8.9$ $\mathrm{Hz}), 7.633(2 \mathrm{H}, \mathrm{d}, J=8.9 \mathrm{~Hz}), 7.482(2 \mathrm{H}, \mathrm{d}$, $J=8.6 \mathrm{~Hz}), 7.369(2 \mathrm{H}, \mathrm{d}, J=8.6 \mathrm{~Hz}), 7.217(1 \mathrm{H}$, d, $J=16.4 \mathrm{~Hz}), 7.115(1 \mathrm{H}, \mathrm{d}, J=16.4)$.

3-Methoxy-4'-nitrostilbene was derived from 3methoxybenzaldehyde and purified by recrystallization from methanol to give light-yellow leaflets (74\%): $\mathrm{mp} 86-87^{\circ} \mathrm{C}$ (Richter (1931): $87^{\circ} \mathrm{C}$ ). NMR $8.227(2 \mathrm{H}, \mathrm{d}, J=8.8 \mathrm{~Hz}), 7.637(2 \mathrm{H}, \mathrm{d}, J=8.8$ $\mathrm{Hz}), 7.35-7.06(5 \mathrm{H}, \mathrm{m}), 6.894(1 \mathrm{H}$, br s$), 3.866$ $(3 \mathrm{H}, \mathrm{s})$.

4-Methoxy-4'-nitrostilbene was synthesized from 4-methoxybenzaldehyde and purified like its 3methoxy isomer to afford yellow crystals (40\%): mp $132-133^{\circ} \mathrm{C}$ (Veschamber and Kergomard, 1966: $\left.131-132^{\circ} \mathrm{C}\right)$. NMR $8.201(2 \mathrm{H}, \mathrm{d}, J=8.8$ $\mathrm{Hz}), 7.590(2 \mathrm{H}, \mathrm{d}, J=8.8 \mathrm{~Hz}), 7.498(2 \mathrm{H}, \mathrm{d}$, $J=8.6 \mathrm{~Hz}), 7.226(1 \mathrm{H}, \mathrm{d}, J=16.4 \mathrm{~Hz}), 7.008(1 \mathrm{H}$, d, $J=16.4 \mathrm{~Hz}), 6.929(2 \mathrm{H}, \mathrm{d}, J=8.6 \mathrm{~Hz}), 3.850$ $(3 \mathrm{H}, \mathrm{s})$.

4-Methyl-4'-nitrostilbene was prepared from 4methylbenzaldehyde and purified by recrystallization from methanol/water to yield yellow-green crystals (62\%): $\mathrm{mp} 150-151^{\circ} \mathrm{C}$ (Veschamber and Kergomard, 1966: $\left.150^{\circ} \mathrm{C}\right)$. NMR $8.210(2 \mathrm{H}$, d, $J=8.9 \mathrm{~Hz}), 7.626(2 \mathrm{H}, \mathrm{d}, J=8.9 \mathrm{~Hz}), 7.450(2 \mathrm{H}$, $\mathrm{d}, J=8.1 \mathrm{~Hz}), 7.248(1 \mathrm{H}, \mathrm{d}, J=16.2 \mathrm{~Hz}), 7.206$ $(2 \mathrm{H}, \mathrm{d}, J=8.1 \mathrm{~Hz}), 7.092(1 \mathrm{H}, \mathrm{d}, J=16.2 \mathrm{~Hz})$, $2.384(3 \mathrm{II}, \mathrm{s})$.

\section{Mutagenicity assays}

Compounds dissolved in DMSO were tested for concentration-mutagenicity relationships using Salmonella typhimurium strains TA98 and TA100 kindly provided by Dr. B.N. Ames, University of California, Berkeley. In addition, the nitroreductase deficient strains TA98/NR and TA100/NR, kindly provided by Dr. H.S. Rosankranz, University of Pittsburgh, were used. The standard plate incorporation assay with and without metabolic activation was used as described by Maron and Ames (1983). Plates were scored with an automatic counter (Autocount, Dynatech Labs, Chantilly, VA) which had been calibrated against manually scored plates. Each 
dose was run in triplicate and the dose-response relationship confirmed in a second set of tests. Linear regression analysis was applied to the initial portion of the dose-response relationships to obtain revertants $/ \mu \mathrm{mol}$ for comparing mutagenic potencies.

\section{Chromosomal aberrations}

Test chemicals were administered ip in DMSO $(2 \mathrm{ml} / \mathrm{kg}$ ) as single $100 \mathrm{mg} / \mathrm{kg}$ doses to each of 4 male $C_{1}$ mice (12 weeks old, 30-35 g, Charles River). Negative control mice were injected with $2 \mathrm{ml} / \mathrm{kg}$ DMSO while DMBA was used as a positive control at a dose of $100 \mathrm{mg} / \mathrm{kg}$ in DMSO. The dose for the test compounds was chosen for comparison to our previous data for the corresponding 4-aminostilbenes (You et al., 1994). CA assays were conducted as previously described (Giri et al., 1989) with a scoring time of $24 \mathrm{~h}$ after injection. All the slides were coded and observed by a single observer where 100 well-spread metaphase cells were scored per animal from each of 4 animals at each concentration tested. Mitotic indices were calculated from 1000 cells/animal and expressed as percentages. The aberration frequencies per cell for chromatid and chromosome types were calculated. Gaps were recorded but not included in the frequency of aberrations per cell.

\section{Results and discussion}

The dose-mutagenicity relationship data for the thirteen test compounds in Salmonella strains TA98, TA100, TA98/NR and TA100/NR with and without the presence of $\mathbf{S} 9$ activation are shown in Table 1. Mutagenicity without the presence of S9 was expected in strains TA100 and TA98 based on the well-established pathway of nitro-group activation by nitroreductases normally present in these strains. However, it was not known whether our nitrostilbenes were equivalent in their ability to serve as substrates for bacterial nitroreductases, which could affect relative mutagenicity determinations. Thus, these compounds were also compared in the nitroreductase-deficient strains TA100NR and TA98NR.
The addition of S9 to the tests was made to better simulate in vivo conditions, where liver transformations should occur not only at the nitrogen site, but could also result in epoxide or arene oxide intermediates. These alternative activation pathways could be more evident in tests with strains TA100NR and TA98NR, where the nitroreductase activation pathway would play a lesser role. Furthermore, the presence of $\mathbf{S} 9$ also affords the opportunity to examine the balance between activation and detoxication pathways that greatly influences potential in vivo activity.

Revertants $/ \mu \mathrm{mol}$ calculations from the linear portion of these relationships are given in Table 2 as estimates of mutagenic potency for TA98 and TA100. The number of doses available for the determination of these values are limited for many of the test compounds because of their poor solubility, resulting in relatively low mutagenicity at the highest dose on the linear portion of the dose-response curve. Confounding the calculations of mutagenic potency further was the problem of reproducibility in the mutagenicity results, which is a well-known problem for nitroarenes (Mermelstein et al., 1985). The number of doses actually used for potency values is indicated in Table 1 and these potency estimates must be used with these qualifications in mind.

All the nitrostilbenes were active in TA98 and TA100 without S9 activation with the exception of 4-amino-4'-nitrostilbene in TA100. However, the nitrostilbenes uniformily had little or no mutagenicity in the nitroreductase deficient strains without S9. This would be consistent with mutagenicity in the former strains being due to activation by bacterial reductase with transformations presumedly to hydroxylamines.

The presence of S9, in general, leads to a decrease in mutagenicity in strains TA98 and TA100. This effect is most likely due to S9 metabolic oxidations resulting in detoxication not enhancement of mutagenicity. The notable exception was enhancement of activity for the 4-amino and 4-methyl derivatives in both strains. In addition, the activation of these two compounds by $S 9$ was also evident in the two nitroreductase deficient strains, TA98/NR and TA100/NR. An explanation for this difference for 4-amino-4'- 
Table 1

Mutagenicity of 4-nitrostilbenes in Salmonella typhimurium a

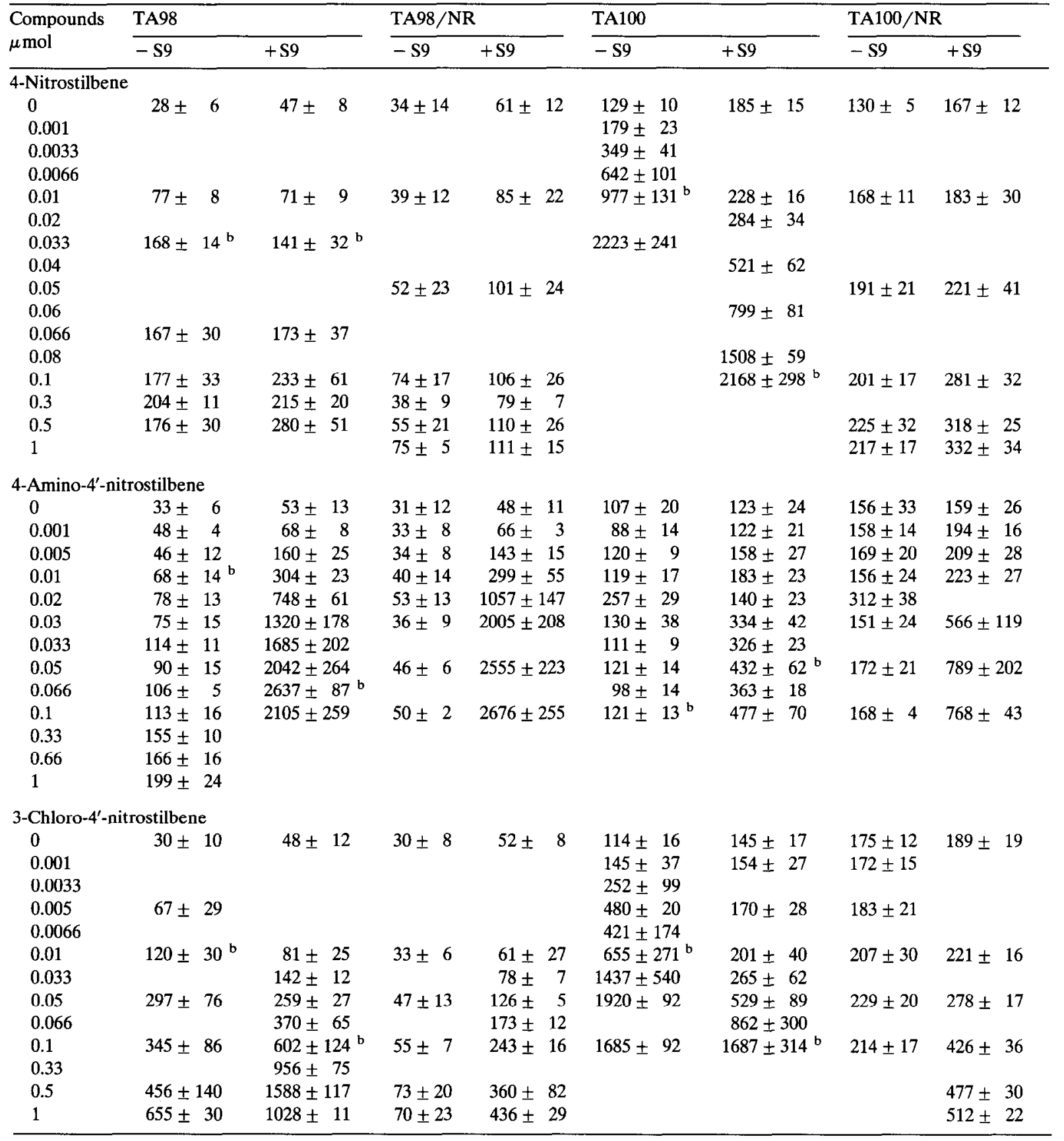


Table 1 (continued)

\begin{tabular}{|c|c|c|c|c|c|c|c|c|}
\hline \multirow{2}{*}{$\begin{array}{l}\text { Compounds } \\
\mu \mathrm{mol}\end{array}$} & \multicolumn{2}{|l|}{ TA98 } & \multicolumn{2}{|l|}{ TA98/NR } & \multicolumn{2}{|l|}{ TA100 } & \multicolumn{2}{|c|}{ TA100/NR } \\
\hline & $-\mathrm{S} 9$ & $+\mathrm{S} 9$ & $-\mathrm{S} 9$ & $+\mathbf{S} 9$ & $-\mathrm{S} 9$ & $+\mathrm{S} 9$ & $-\mathrm{S} 9$ & $+\mathrm{S} 9$ \\
\hline \multicolumn{9}{|c|}{ 4-Chloro-4'-nitrostilbene } \\
\hline 0 & $38 \pm 6$ & $60 \pm 11$ & $34 \pm 14$ & $66 \pm 6$ & $105 \pm 16$ & $124 \pm 20$ & $135 \pm 18$ & $158 \pm 14$ \\
\hline 0.001 & $51 \pm 7$ & $67 \pm 13$ & $37 \pm 3$ & $70 \pm 9$ & $118 \pm 14$ & $136 \pm 17$ & $138 \pm 9$ & $170 \pm 16$ \\
\hline 0.005 & $118 \pm 7$ & $70 \pm 18$ & $39 \pm 15$ & $79 \pm 6$ & $123 \pm 12$ & $164 \pm 17$ & $156 \pm 7$ & $192 \pm 20$ \\
\hline 0.01 & $183 \pm 10^{b}$ & $93 \pm 15$ & $50 \pm 8$ & $80 \pm 4$ & $150 \pm 22 b$ & $180 \pm 16^{b}$ & $161 \pm 13$ & $177 \pm 17$ \\
\hline 0.05 & $203 \pm 18$ & $208 \pm 25^{b}$ & $63 \pm 15$ & $128 \pm 11$ & $155 \pm 20$ & $231 \pm 23$ & $166 \pm 18$ & $230 \pm 21$ \\
\hline 0.1 & $227 \pm 21$ & $262 \pm 36$ & $77 \pm 15$ & $169 \pm 19$ & $167 \pm 22$ & $265 \pm 12$ & $166 \pm 33$ & $282 \pm 23$ \\
\hline 0.5 & & & $79 \pm 2$ & $164 \pm 13$ & & & & \\
\hline 1 & & & $82 \pm 4$ & $188 \pm 17$ & & & & \\
\hline \multicolumn{9}{|c|}{ 3-Cyano-4'-nitrostilbene } \\
\hline $\begin{array}{l}0 \\
0.0005\end{array}$ & $22 \pm 6$ & $49 \pm 10$ & $33 \pm 7$ & $54 \pm 10$ & $\begin{array}{l}120 \pm 21 \\
160 \pm 64\end{array}$ & $145 \pm 20$ & $166 \pm 11$ & $181 \pm 18$ \\
\hline $\begin{array}{l}0.001 \\
0.0033\end{array}$ & $54 \pm 22$ & & $30 \pm 5$ & & $\begin{array}{l}203 \pm 95 \\
451 \pm 205\end{array}$ & $167 \pm 30$ & $164 \pm 13$ & $181 \pm 17$ \\
\hline $\begin{array}{l}0.005 \\
0.0066\end{array}$ & $208 \pm 55$ & & $34 \pm 3$ & & $773 \pm 373$ & $183 \pm 44$ & $177 \pm 16$ & $189 \pm 10$ \\
\hline 0.01 & $420 \pm 118^{b}$ & $82 \pm 14$ & $61 \pm 11$ & $79 \pm 14$ & $1076 \pm 440^{b}$ & $249 \pm 73$ & $192 \pm 20$ & $194 \perp 9$ \\
\hline 0.02 & & & & & & $574 \pm 234$ & & \\
\hline 0.033 & $929 \pm 287$ & $362 \pm 63$ & & $68 \pm 8$ & & $1224 \pm 221^{b}$ & & \\
\hline 0.05 & $1167 \pm 348$ & $628 \pm 130$ & $114 \pm 21$ & $149 \pm 38$ & & & $211 \pm 31$ & $258 \pm 11$ \\
\hline 0.066 & & $1005 \pm 153$ & & $114 \pm 9$ & & & & \\
\hline 0.1 & & $1579 \pm 165^{b}$ & $149 \pm 26$ & $167 \pm 31$ & & & $217 \pm 42$ & $319 \pm 27$ \\
\hline 0.33 & & & $179 \pm 26$ & $282 \pm 45$ & & & & \\
\hline 0.66 & & & $143 \pm 19$ & $377 \pm 70$ & & & & \\
\hline 1 & & & $150 \pm 16$ & $406 \pm 32$ & & & & \\
\hline \multicolumn{9}{|c|}{ 4-Cyano-4'-nitrostilbene } \\
\hline $\begin{array}{l}0 \\
0.001\end{array}$ & $33 \pm 9$ & $59 \pm 9$ & $33 \pm 7$ & $54 \pm 10$ & $\begin{array}{l}118 \pm 21 \\
141 \pm \quad 8\end{array}$ & $\begin{array}{l}146 \pm 19 \\
164 \pm 14\end{array}$ & $166 \pm 11$ & $181 \pm 18$ \\
\hline 0.005 & $146 \pm 18$ & & $50 \pm 3$ & & $260 \pm 71$ & $214 \pm 53$ & & \\
\hline 0.01 & $181 \pm 47^{b}$ & $123 \pm 20$ & $50 \pm 11$ & $68 \pm 10$ & $318 \pm 90^{b}$ & $347 \pm 84^{b}$ & $159 \pm 12$ & $214 \pm 26$ \\
\hline 0.05 & $280 \pm 73$ & $187 \pm 19^{b}$ & $58 \pm 14$ & $95 \pm 13$ & $504 \pm 122$ & $566 \pm 84$ & $181 \pm 19$ & $242 \pm 16$ \\
\hline 0.1 & $346 \pm 137$ & $218 \pm 33$ & $61 \pm 9$ & $91 \pm 15$ & $573 \pm 154$ & $643 \pm 63$ & $172 \pm 11$ & $225 \pm 17$ \\
\hline 0.5 & $345 \pm 109$ & $265 \pm 41$ & $66 \pm 17$ & $95 \pm 14$ & $535 \pm 201$ & $758 \pm 90$ & $178 \pm 11$ & $244 \pm 21$ \\
\hline 1 & $448 \pm 41$ & $274 \pm 63$ & $80 \pm 17$ & $111 \pm 13$ & & & $166 \pm 10$ & $250 \pm 27$ \\
\hline \multicolumn{9}{|c|}{ 3-Methoxy-4'-nitrostilbene } \\
\hline 0 & $36 \pm 6$ & $65 \pm 10$ & $32 \pm 8$ & $51 \pm 7$ & $125 \pm 21$ & $160 \pm 20$ & $175 \pm 12$ & $189 \pm 19$ \\
\hline 0.0005 & & & & & $143 \pm 13$ & & & \\
\hline 0.001 & & & & & $185 \pm 11$ & & $170 \pm 20$ & \\
\hline 0.0033 & & & & & $390 \pm 21$ & & & \\
\hline 0.005 & $78 \pm 12$ & & $40 \pm 6$ & $81 \pm 12$ & & & $192 \pm 15$ & \\
\hline 0.0066 & & & & & $793 \pm 107^{b}$ & & & \\
\hline 0.01 & $119 \pm 20^{b}$ & $92 \pm 10$ & $38 \pm 11$ & $69 \pm 15$ & $898 \pm 74$ & $218 \pm 13$ & $202 \pm 13$ & $207 \pm 20$ \\
\hline 0.033 & $234 \pm 31$ & $100 \pm 14$ & & & & $363 \pm 35$ & $260 \pm 20$ & \\
\hline 0.05 & $292 \pm 27$ & $125 \pm 12$ & $70 \pm 21$ & $74 \pm 13$ & & & $415 \pm 71$ & $250 \pm 16$ \\
\hline 0.066 & $224 \pm 23$ & $156 \pm 12$ & & & & $756 \pm 38$ & $409 \pm 20$ & \\
\hline 0.1 & & $209+23^{b}$ & $107 \pm 32$ & $115 \pm 29$ & & $1108 \pm 143^{b}$ & $565 \pm 53$ & $319 \pm 10$ \\
\hline 0.3 & & & $101 \pm 13$ & $160 \pm 29$ & & & & $901 \pm 50$ \\
\hline 0.33 & & & & & & $109 \pm 31$ & & \\
\hline 0.5 & & & $122 \pm 33$ & $467 \pm 93$ & & & & $1342 \pm 195$ \\
\hline 1 & & & & $311 \pm 28$ & & & & \\
\hline
\end{tabular}


Table 1 (continued)

\begin{tabular}{|c|c|c|c|c|c|c|c|c|c|}
\hline \multirow{2}{*}{$\begin{array}{l}\text { Compounds } \\
\mu \mathrm{mol}\end{array}$} & \multicolumn{2}{|l|}{ TA98 } & \multicolumn{2}{|c|}{ TA98/NR } & \multicolumn{2}{|l|}{ TA100 } & \multicolumn{3}{|c|}{ TA100/NR } \\
\hline & $-\mathrm{S} 9$ & $+\$ 9$ & $-\mathrm{S9}$ & $+\mathrm{S} 9$ & $-\mathrm{S9}$ & $+\mathbf{S} 9$ & $-\mathrm{S} 9$ & $+\mathrm{S} 9$ & \\
\hline \multicolumn{10}{|c|}{ 4-Methoxy-4'-nitrostilbene } \\
\hline 0 & $31 \pm 6$ & $54 \pm 11$ & $33 \pm 5$ & $57 \pm 12$ & $140 \pm 28$ & $137 \pm 14$ & $175 \pm 12$ & $189 \pm 1$ & 19 \\
\hline 0.001 & $49 \pm 8$ & & & & $213 \pm 22$ & & $166 \pm 16$ & & \\
\hline 0.0033 & & & & & $339 \pm 48$ & & & & \\
\hline 0.005 & $58 \pm 4$ & & & & $697 \pm 20$ & $175 \pm 8$ & $174 \pm 18$ & & \\
\hline 0.0066 & & & & & $604 \pm 76$ & & & & \\
\hline 0.01 & $71 \pm 22^{b}$ & $75 \pm 20$ & $37 \pm 8$ & $83 \pm 19$ & $774 \pm 91^{b}$ & $242 \pm 6$ & $204 \pm 10$ & $206 \pm 1$ & 19 \\
\hline 0.033 & & & & & $1077 \pm 81$ & $346 \pm 76$ & & & \\
\hline 0.05 & $79 \pm 22$ & $140 \pm 37$ & $52 \pm 21$ & $87 \pm 9$ & & & $225 \pm 32$ & $227 \pm 1$ & 14 \\
\hline 0.066 & & & & & $417 \pm 19$ & $797 \pm 148$ & & & \\
\hline 0.1 & $90 \pm 18$ & $201 \pm 44^{b}$ & $51 \pm 5$ & $113 \pm 27$ & $169 \pm 26$ & $1283 \pm 100^{b}$ & $200 \pm 6$ & $302 \pm 4$ & 47 \\
\hline 0.5 & $75 \pm 4$ & $248 \pm 34$ & $50 \pm 21$ & $118 \pm 14$ & & & & $264 \pm 1$ & 17 \\
\hline 1 & $106 \pm 20$ & $253 \pm 28$ & $47 \pm 8$ & $107 \pm 15$ & & & & $320 \pm 1$ & 18 \\
\hline \multicolumn{10}{|c|}{ 4-Methyl-4'-nitrostilbene } \\
\hline 0 & $33 \pm 9$ & $48 \pm 6$ & $36 \pm 6$ & $59 \pm 9$ & $116 \pm 6$ & $154 \pm 17$ & $121 \pm 19$ & $146 \pm 1$ & 13 \\
\hline 0.0005 & & & & & & $285 \pm 24$ & & & \\
\hline 0.001 & & $150 \pm 6$ & & & $140 \pm 18$ & $413 \pm 32^{b}$ & & $158 \pm 1$ & 12 \\
\hline 0.0033 & & & & & $233 \pm 22$ & $822 \pm 124$ & & & \\
\hline 0.005 & $52 \pm 9$ & $368 \pm 43$ & & & & & $134 \pm 14$ & $194 \pm 2$ & 24 \\
\hline 0.0066 & & & & & $401 \pm 42$ & $946 \pm 50$ & & & \\
\hline 0.01 & $82 \pm 17^{b}$ & $576 \pm 38^{b}$ & $47 \pm 7$ & $162 \pm 17$ & $600 \pm 128^{b}$ & $1071 \pm 55$ & $149 \pm 11$ & $265 \pm 1$ & 18 \\
\hline 0.033 & & $1078 \pm 71$ & & $314 \pm 15$ & & & & $501 \pm 4$ & 43 \\
\hline 0.05 & $100 \pm 22$ & $1413 \pm 183$ & $45 \pm 7$ & $477 \pm 94$ & $1000 \pm 85$ & & $133 \pm 14$ & $843 \pm 13$ & \\
\hline 0.066 & & & & $549 \pm 66$ & & & & $809 \pm 9$ & 91 \\
\hline 0.1 & $119 \pm 17$ & $38 \pm 12$ & $41 \pm 8$ & $658 \pm 36$ & & & $147 \pm 11$ & $939 \pm 3$ & 36 \\
\hline 0.5 & $129 \pm 8$ & $0 \pm 1$ & $50 \pm 11$ & $806 \pm 51$ & & & $135 \pm 18$ & & \\
\hline 1 & & & $59 \pm 13$ & $813 \pm 52$ & & & & & \\
\hline \multicolumn{10}{|c|}{ 3,4'-Dinitrostilbene } \\
\hline 0 & $39 \pm 6$ & $74 \pm 8$ & $22 \pm 3$ & $51 \pm 5$ & $129 \pm 10$ & $168 \pm 15$ & $142 \pm 18$ & $169 \pm 1$ & 12 \\
\hline 0.001 & $121 \pm 32$ & & & & $288 \pm 27$ & & $158 \pm 13$ & $161 \pm 1$ & 13 \\
\hline 0.0033 & $299 \pm 54^{b}$ & & & & $667 \pm 49$ & & & & \\
\hline 0.005 & & & & & $1032 \pm 143$ & & $160 \pm 4$ & $154 \pm$ & 4 \\
\hline 0.0066 & $463 \pm 42$ & & & & $1112 \pm 59^{b}$ & & & & \\
\hline 0.01 & $530 \pm 40$ & & $45 \pm 5$ & $63 \pm 11$ & $1122 \pm 97$ & $202 \pm 9$ & $160 \pm 12$ & $177 \pm 2$ & 23 \\
\hline 0.02 & & $112 \pm 12$ & & & & & & & \\
\hline 0.033 & $740 \pm 28$ & & & & & & & & \\
\hline 0.04 & & $161 \pm 19$ & & & & & & & \\
\hline 0.05 & & & $56 \pm 6$ & $69 \pm 8$ & $1904 \pm 52$ & $431 \pm 34^{b}$ & $165 \pm 19$ & $187 \pm 1$ & 12 \\
\hline 0.06 & & $197 \pm 19$ & & & & & & & \\
\hline 0.08 & & $219 \pm 27^{b}$ & & & & & & & \\
\hline 0.1 & & $228 \pm 12$ & $62 \pm 12$ & $85 \pm 17$ & $1789 \pm 49$ & $558 \pm 37$ & $156 \pm 20$ & $196 \pm 1$ & 11 \\
\hline 0.3 & & & $63 \pm 13$ & $84 \pm 16$ & & & & & \\
\hline 0.5 & & & $55 \pm 9$ & $89 \pm 12$ & & $676 \pm 46$ & $164 \pm 6$ & $218 \pm 1$ & 18 \\
\hline 1 & & & $39 \pm 3$ & $98 \pm 12$ & & $723 \pm 36$ & $149 \pm 19$ & $192 \pm 3$ & 33 \\
\hline
\end{tabular}


Table 1 (continued)

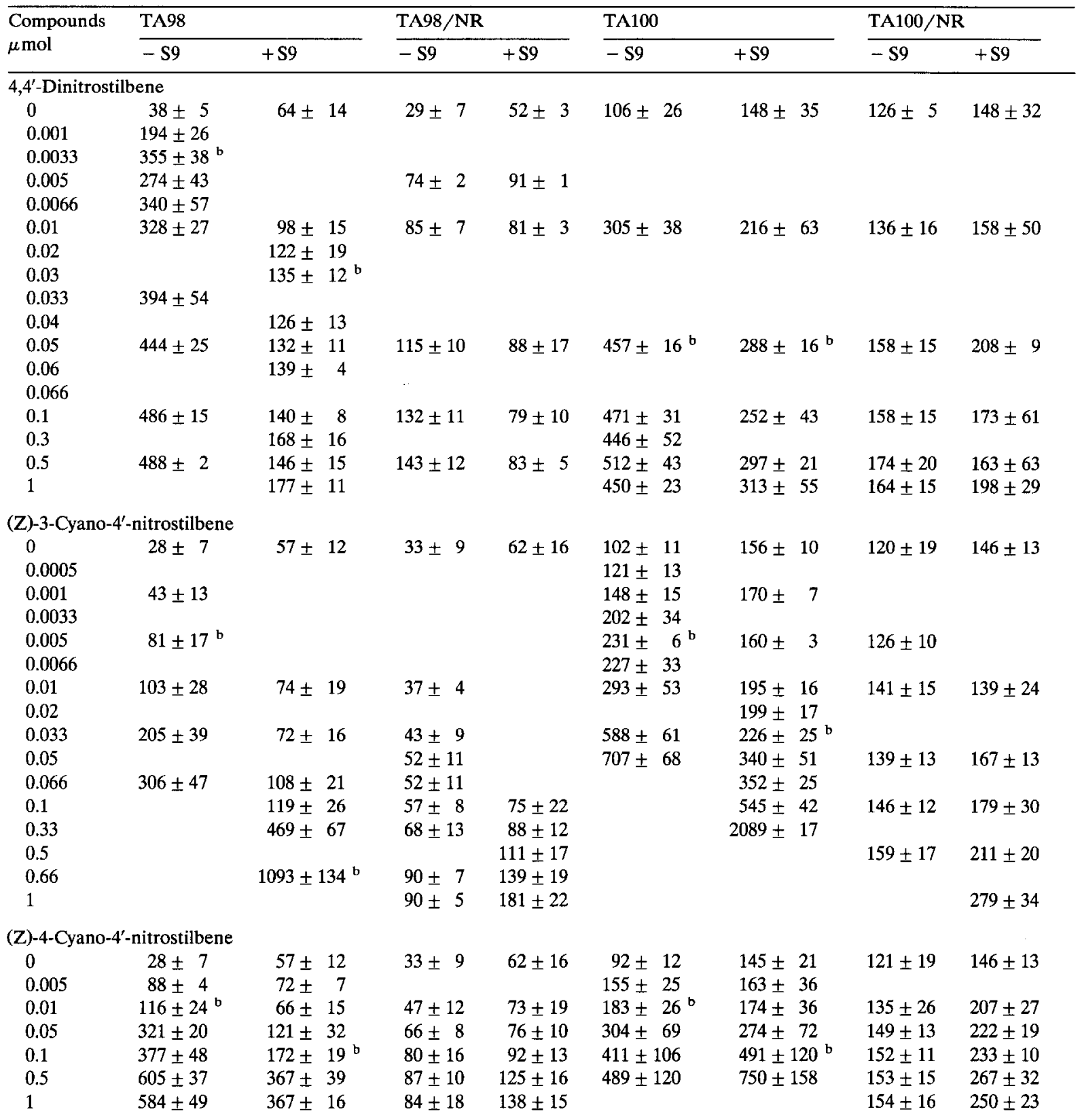

a Combined data from at least two independent experiments, with triplicate plating per dose and at least 5 doses per experiment (except for 4,4-dinitrostilbene with strain TA98/NR, where only one experiment was performed).

${ }^{b}$ Indicates highest dose included in linear regression analysis, with a minimum of measurements at three levels. 
Table 2

Mutagenicity (revertants $/ \mu$ mole) of $4^{\prime}$-nitrostilbenes in Salmonella typhimurium strains TA98 and TA100 a

\begin{tabular}{|c|c|c|c|c|}
\hline \multirow[t]{2}{*}{ Substituent } & \multicolumn{2}{|l|}{ TA98 } & \multicolumn{2}{|l|}{ TA100 } \\
\hline & $-S 9$ & $+\mathbf{S 9}$ & $-\mathrm{S} 9$ & $+\mathrm{S} 9$ \\
\hline 4-Nitrostilbene & $4208 \pm 139$ & $2884 \pm 270$ & $85495 \pm 3809$ & $18287 \pm 1137$ \\
\hline 4-Amino & $3368 \pm 410$ & $41383 \pm 975$ & 0 & $6276 \pm 249$ \\
\hline 3-Chloro & $9001 \pm 999$ & $5590 \pm 249$ & $54454 \pm 5245$ & $14820 \pm$ \\
\hline 4-Chloro & $14685 \pm 420$ & $2959 \pm 160$ & $4028 \pm 838$ & $5448 \pm$ \\
\hline 3-Cyano & $39958 \pm 2736$ & $15798 \pm 530$ & $97146 \pm 9151$ & $31909 \pm 1926$ \\
\hline 4-Cyano & $14732 \pm 1639$ & $2295 \pm 217$ & $20232 \pm 2953$ & $19890 \pm 2540$ \\
\hline 3-Methoxy & $8256 \pm 766$ & $1369 \pm 77$ & $102469 \pm 4088$ & $9691 \pm 379$ \\
\hline 4-Methoxy & $3604 \pm 758$ & $1454 \pm 156$ & $65042 \pm 3638$ & $11252 \pm$ \\
\hline 4-Methyl & $4942 \pm 692$ & $51899 \pm 2206$ & $48854 \pm 3011$ & $259712 \pm 14106$ \\
\hline 3-Nitro & $78558 \pm 5998$ & $1871 \pm 120$ & $164166 \pm 7814$ & $5381 \pm 250$ \\
\hline 4-Nitro & $97497 \pm 7247$ & $2481 \pm 305$ & $6413 \pm 1010$ & $2614 \pm$ \\
\hline (Z)-3-Cyano & $10277 \pm 1385$ & $1535 \pm 54$ & $26349 \pm 2199$ & $5693 \pm$ \\
\hline (Z)-4-Cyano & $8774 \pm 992$ & $1150 \pm 95$ & $9030 \pm 1096$ & $3369 \pm$ \\
\hline
\end{tabular}

${ }^{\mathrm{a}}$ Values are the calculated slopes (rev/ $\mu$ mole) of the linear portion of the dose-response curve derived from the data in Table 1.

nitrostilbene could be that this compound is functioning as an activated aminostilbene with oxidation of the amino moiety by S9 to the hydroxylamine rather than reduction of the nitro group occurring prior to DNA adduct formation. In regards to the methyl derivative, it is possible that hydroxylation of the methyl group is involved in the activation of this compound. For example, Hanna et al. (1980) have reported for 4'-methyl4-aminostilbene that such hydroxylation occurs more readily than the usual $\mathrm{N}$-hydroxylation of these compounds by hamster hepatic microsomes.
The $3^{\prime}$ and 4' Z-cyano isomers,<smiles>O=[N+]([O-])C1CCC(C=C2CC=CC2)CC1</smiles>
study to examine the effect of geometric differences on genotoxicity. For both TA98 and TA100, with and without S9 activation, the Z-isomers were markedly less mutagenic than the corresponding E-isomers. This might be explained by steric hinderance in the Z-isomers reducing the conjugation between the phenyl rings, where such conjugation with the E-isomcrs promotes mutagenicity (Sinsheimer et al., 1992).

Table 3

Physicochemical parameters for the 4-nitrostilbene series

\begin{tabular}{lrrrrr}
\hline Substituent & \multicolumn{1}{c}{$\sigma^{\mathrm{a}}$} & \multicolumn{1}{c}{${ }^{+\mathrm{a}}$} & \multicolumn{1}{c}{$E_{\text {HOMO }}{ }^{\mathrm{b}}$} & \multicolumn{1}{c}{$E_{\text {LUMO }}{ }^{\mathrm{b}}$} & $\pi_{\text {HPLC }}{ }^{\mathrm{c}}$ \\
\hline 4-Nitrostilbene & 0.00 & 0.00 & -9.289 & -1.406 & 0.75 \\
4-Amino & -0.66 & -1.30 & -8.233 & -1.244 & 0.92 \\
3-Chloro & 0.37 & 0.40 & -9.380 & -1.499 & 0.79 \\
4-Chloro & 0.23 & 0.11 & -9.238 & -1.495 & 0.83 \\
3-Cyano & 0.56 & 0.56 & -9.637 & -1.601 & 0.40 \\
4-Cyano & 0.66 & 0.66 & -9.610 & -1.662 & 0.43 \\
3-Methoxy & 0.12 & 0.05 & -9.212 & -1.443 & 0.70 \\
4-Methoxy & -0.27 & -0.78 & -9.014 & -1.374 & 0.86 \\
4-Methyl & -0.17 & -0.31 & -9.150 & -1.386 & 0.92 \\
3-Nitro & 0.71 & 0.67 & -9.812 & -1.735 & 0.56 \\
4-Nitro & 0.78 & 0.79 & -9.949 & -1.908 & 0.60 \\
\hline
\end{tabular}

${ }^{a}$ Hammett values taken from Hansch and Leo (1979).

b Frontier orbital energies calculated as previously described (You et al., 1993).

${ }^{c}$ Partition coefficients determined by the method of Carlson et al. (1975) using our previously described experimental conditions (You et al., 1993) with methanol/water $(6: 4)$ as eluting solvent. 


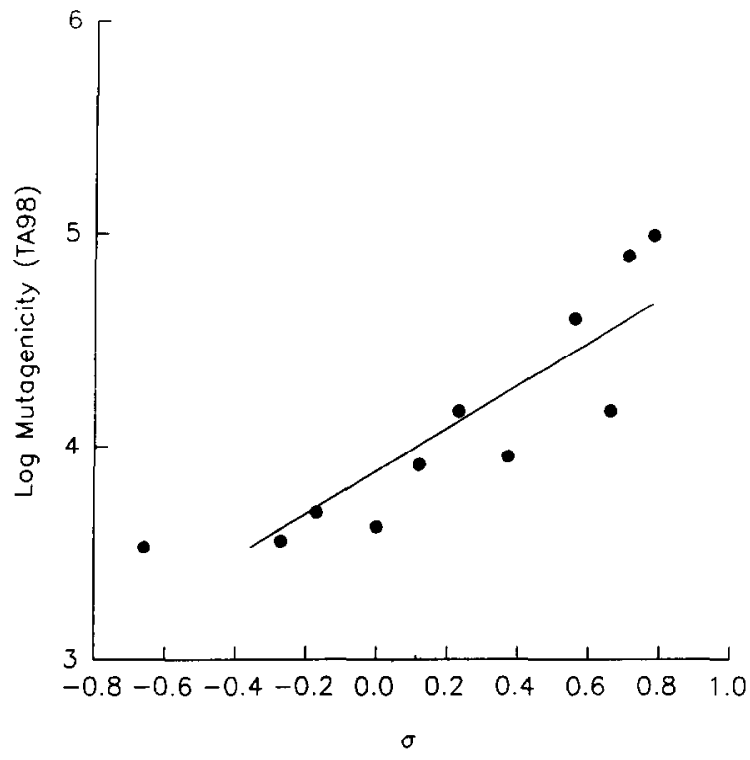

Fig. 1. Relationship between electron withdrawing capability, as measured by Hammett $\sigma$ values and mutagenicity towards Salmonella tester strain TA98.

Table 3 lists the physicochemical parameters used in the QSAR analysis of the mutagenicity of the electron-donating/withdrawing ability of nitrostilbenes. These include Hammett $\sigma$ and $\sigma^{+}$ values for the meta' and para' substituents of the test compounds, frontier orbital energies (lowest unoccupied and highest occupied molecular orbitals; $E_{\text {LUMO }}$ and $E_{\text {HOMO }}$ ) and partition coefficients $\left(\pi_{\text {HPLC }}\right)$. Correlations could be established for the nitrostilbenes between mutagenicity in strain TA98, without S9 activation, and electrondonating/withdrawing ability of substituent groups (Table 4; Fig. 1). Compounds with strong electron-withdrawing substituent groups were generally more mutagenic. In the present study, $\sigma$ Hammet values were a somewhat better predictor of mutagenic activty than $\sigma^{+}$values while the reverse was true for the aminostilbenes. The electron-withdrawing effects of the substituents on the mutagenicity of the nitrostilbenes were similar to those we previously developed for $3,3^{\prime}$ disubstituted benzidine derivatives (You et al., 1993) as well as for 4-aminobiphenyl and 4aminostilbene derivatives (You et al., 1994). These effects are consistent with the concepts developed by Vance et al. (1987) for fluorene derivatives. That is, electron-withdrawing groups could help stabilize hydroxylamines, the proximate mutagens for both amino and nitro species, and allow for longer lifetimes for the hydroxylamines with an increased probability to interact with DNA. Also, a destabilization effect by clectronwithdrawing groups on nitrenium ions, the subsequent ultimate mutagens, could increase their reactivity with DNA.

The correlation for the mutagenicity of nitrostilbenes to the electron-withdrawing ability of their substituents could also be explained by substituent effects on the reduction of the nitro group as electron-withdrawing groups should favor this process. The correlation of increased mutagenicity in TA98 with decreasing $E_{\text {LUMO }}$ values for the nitrostilbenes (Table 4) also supports the importance of nitro group reduction for mutagenic potency, as decreased $E_{\text {Lumo }}$ values are indicative of a more easily reduceable compound. The lack of a similar reduction step for the corresponding amino compounds would explain the weaker correlation between their mutagenicity and $E_{\text {LUMO }}$ values. These correlations of

Table 4

Correlation coefficients $\left(r^{2}\right)$ for the regression equations between mutagenicity and physicochemical parameters ${ }^{\text {a }}$

\begin{tabular}{lllllll}
\hline & $\sigma$ & $\sigma^{+}$ & $E_{\text {HOMO }}$ & $E_{\text {LUMO }}$ & $\pi_{\text {HPLC }}$ & $E_{\text {HOMO }}+E_{\text {LUMO }}$ \\
\hline 4-Nitrostilbenes & & & & & & 0.87 \\
TA98 & 0.77 & 0.66 & 0.68 & 0.87 & 0.52 & 0.92 \\
TA100 & 0.28 & 0.37 & 0.49 & 0.13 & 0.16 & \\
4-Aminostilbenes & & & & & & 0.63 \\
TA98 & 0.70 & 0.79 & 0.63 & 0.51 & 0.13 & 0.84 \\
TA100 & 0.30 & 0.46 & 0.36 & 0.09 & 0.16 &
\end{tabular}

${ }^{a}$ Values for the nitrostilbenes are based on the mutagenicity results without S9 activation while those for the aminostilbenes were taken from You et al. (1994) and are with S9 activation. 
electronic effects of substituents are in agreement with the reports of Klopman et al. (1984), Debnath et al. (1991; 1992b) and Maynard et al. (1986) for other nitro aromatic compounds. However, in contrast to the work of Debnath et al. (1992a;b), there was no evidence of a relationship between hydrophobicity and mutagenicity, either alone or in combination with one of the electronic parameters, for these series of closely related nitro or amino stilbenes.

The mutagenicity for 4 -cyano-4'-nitrostilbene in TA98 is less than that which would be expected based upon its Hammet values and that of two other nitrostilbenes, the 4-chloro and 4-nitro derivatives. This effect by a cyano group at a conjugating position with the mutagenic center has been observed previously in our aminobiphenyl and aminostilbene series (You et al., 1994) and has been reported by Vance et al., (1987) for their fluorenes. One explanation could be that the 4-cyano-substituted proximate mutagen (I) has a resonance form (II) which can lead to an oxime (III). Hydrolysis of this oxime would then result in species which are unable to form nitrenium ions.

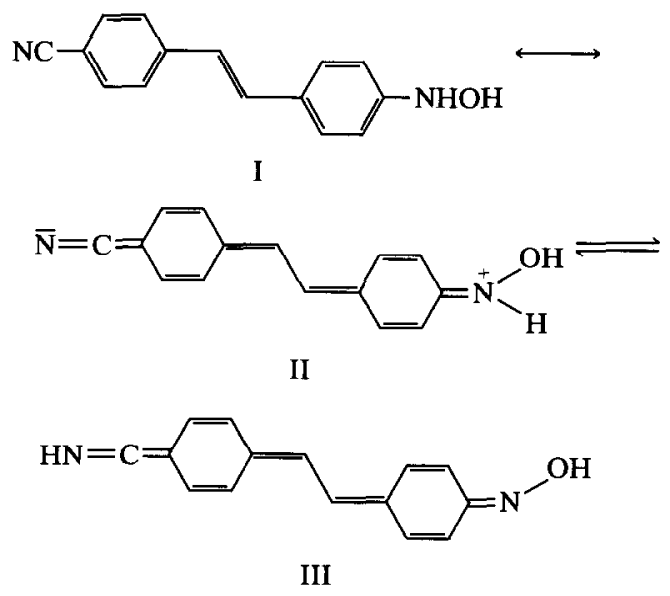

Unlike the results in TA98, there was little correlation between mutagenicity of the nitrostilbenes in TA100 and any individual physicochemical parameter. This strain difference is similar to that found for the 4-aminostilbenes, and was attributed (You et al., 1994) to the differential

Table 5

In vivo chromosomal aberrations induced by $4^{\prime}$-nitrostilbenes at $100 \mathrm{mg} / \mathrm{kg}$ a

\begin{tabular}{|c|c|c|c|c|c|}
\hline \multirow[t]{2}{*}{ Substituent } & \multirow[t]{2}{*}{ Gaps ${ }^{b}$} & \multicolumn{2}{|c|}{ Aberrations/cell } & \multirow{2}{*}{$\begin{array}{l}\text { Aberrant cells }(\%)^{c} \\
(\text { mean } \pm S D)^{d}\end{array}$} & \multirow{2}{*}{$\begin{array}{l}\text { Mitotic indices }(\%) \\
(\text { mean } \pm \text { SD) }\end{array}$} \\
\hline & & $\begin{array}{l}\text { Chromatid } \\
\text { type }\end{array}$ & $\begin{array}{l}\text { Chromosome } \\
\text { type }\end{array}$ & & \\
\hline $\begin{array}{l}\text { Solvent control } \\
\text { DMSO }(2 \mathrm{ml} / \mathrm{kg})\end{array}$ & 3.00 & 0.010 & 0.000 & $1.00 \pm 0.82$ & $3.51 \pm 0.30$ \\
\hline $\begin{array}{l}\text { Positive control } \\
\text { DMBA }\end{array}$ & 11.25 & 0.115 & 0.023 & $13.25 \pm 0.96^{* *}$ & $2.13 \pm 0.12 * *$ \\
\hline 4-Aminostilbene & 4.75 & 0.063 & 0.000 & $6.00 \pm 0.82 * *$ & $2.79 \pm 0.34^{* *}$ \\
\hline 4-Amino & 3.75 & 0.043 & 0.008 & $5.00 \pm 0.82 * *$ & $1.95 \pm 0.29 * *$ \\
\hline 3-Chloro & 4.00 & 0.040 & 0.005 & $4.50 \pm 0.58 * *$ & $2.27 \pm 0.31 * *$ \\
\hline 4-Chloro & 3.25 & 0.030 & 0.003 & $3.00 \pm 0.82 * *$ & $2.38 \pm 0.29 * *$ \\
\hline 3-Cyano & 3.50 & 0.040 & 0.008 & $4.75 \pm 0.50 * *$ & $2.31 \pm 0.37 * *$ \\
\hline 4-Cyano & 3.00 & 0.028 & 0.000 & $2.75 \pm 0.50 * *$ & $2.53 \pm 0.44 * *$ \\
\hline 3-Methoxy & 3.00 & 0.028 & 0.000 & $2.75 \pm 0.50^{* *}$ & $2.50 \pm 0.34 * *$ \\
\hline 4-Methoxy & 3.00 & 0.033 & 0.000 & $3.25 \pm 0.50 * *$ & $2.45 \pm 0.47 * *$ \\
\hline 4-Methyl & 5.25 & 0.040 & 0.010 & $5.00 \pm 0.82 * *$ & $2.33 \pm 0.28 * *$ \\
\hline (Z)-3-Cyano & 3.25 & 0.023 & 0.000 & $2.25 \pm 0.96 *$ & $2.80 \pm 0.46 *$ \\
\hline (Z)-4-Cyano & 3.25 & 0.023 & 0.000 & $2.25 \pm 0.50 *$ & $2.78 \pm 0.39 *$ \\
\hline
\end{tabular}

a The two dinitro compounds were insoluble in a suitable solvent and could not be tested.

b Total chromatid and chromosome gaps at each concentration per 100 cells were recorded but not included as aberrations.

c Cells with at least 1 aberration for 4 animals.

${ }^{d}$ Results were compared to those of the control, where statistically significant differences are indicated by $*<0.05$ and ** $P<0.01$ by Student's $t$-test. 
sensitivities of the strains to the type of adduct formed by the compounds. The planar structure of the stilbenes promotes DNA interactions, which are believed to lead to the frameshift mutations more readily recognized by TA98 but not by TA100. Curiously, both stilbene series showed an increased level of correlation when both frontier orbital energies were incorporated into the equation to describe mutagenicity in TA100 $\left(r^{2}\right.$ $=0.84$ for the aminostilbenes with $\mathrm{S} 9$ activation, $r^{2}=0.91$ for the nitrostilbenes without $\mathrm{S} 9$ addition). However, the increased correlation may be a function of the collinearity between $E_{\text {номо }}$ and $E_{\text {LUMO }}$ resulting in a fortuitous correlation (Topliss and Edward, 1979).

The CA results induced in the bone-marrow cells of mice are given in Table 5 where the conditions are the same as those used for our previous study of the corresponding aminostilbenes (You et al., 1994). Unfortunately, the insolubility of the dinitro compounds in a suitable solvent for CA testing did not allow their examination in this manner. All the other compounds produced a statistically significant increase in aberrant cells and a decrease in mitotic index compared to the negative solvent control. The differences among compounds in the present study is more muted than was the case for our previous aminostilbene study, where the parent 4-aminostilbene, the methyl, 3-methoxy, 3-chloro and 3-cyano compounds all exhibited greater CA responses than their corresponding nitrostilbenes. While the parent unsubstituted 4-aminostilbene was clearly more genotoxic than any of its derivatives, the parent 4-nitrostilbene in the present study can only be established as among the more genotoxic compounds but not significantly greater than several of its derivatives. Also, while all the nitrustilbenes with substituents in the 3-position were more genotoxic in vivo than their 4-isomers, a statistically significant difference could not be established between the methoxy or the (Z)-cyano isomer pairs.

The relationship between mutagenicity and electronic effects of substituent groups found in vitro could not be extended to the in vivo $\mathrm{CA}$ results. Thus, in vitro QSAR results for the nitrostilbenes, as was true for our related aromatic amines, were not predictive of in vivo bone-marrow CA effects, where such factors as biological half-lives, metabolic transformations and detoxication mechanisms would have a more important role.

\section{Acknowledgements}

This investigation was supported by grant R01 ES 05047 from the National Institute of Environmental Health Sciences, DHHS.

\section{References}

Beland, F.A., and F.F. Kadlubar (1990) Metabolic activation and DNA adducts of aromatic amines and nitroaromatic hydrocarbons, in: C.S. Cooper and P.L. Grover (Eds.), Chemical Carcinogenesis and Mutagenesis I, SpringerVerlag, Berlin, pp. 267-325.

Carlson, R.M., R.E. Carlson and H.L. Kopperman (1975) Determination of partition coefficients by liquid chromatography, J. Chromatogr., 107, 219-223.

Debnath, A.K., R.L.L. de Compadre, G. Debnath, A.J. Shusterman and C. Hansch (1991) Structure-activity relationship of mutagenic aromatic and heteroaromatic nitro compounds. Correlation with molecular orbital energies and hydrophobicity, J. Med. Chem., 34, 786-797.

Debnath, A.K., G. Debnath, A.J. Shusterman and C. Hansch (1992a) A QSAR investigation of the role of hydrophobicity in regulating mutagenicity in the Ames test: 1 . Mutagenicity of aromatic and heteroaromatic amines in Salmonella typhimurium TA98 and TA100, Environ. Mol. Mutagen., 19, 37-52.

Debnath, A.K., R.L.L. de Compadre, A.J. Shusterman and C. Hansch (1992b) Quantitative structure-activity relationship investigation of the role of hydrophobicity in regulating mutagenicity in the Ames test: 2 . Mutagenicity of aromatic and heteroaromatic nitro compounds in Salmonella typhimurium TA100, Environ. Mol. Mutagen., 19, 53-70.

Giri, A.K., E.A. Messerly and J.E. Sinsheimer (1989) Sisterchromatid exchange and chromosome aberrations for 4 aliphatic epoxides in mice, Mutation Res., 224, 253-261.

Hanna, P.E., R.E. Gammans, R.D. Sehon and M.-K. Lee (1980) Metabolic N-hydroxylation. Use of substituent variation to modulate the in vitro bioactivation of 4-acetamidostilbenes, J. Med. Chem., 23, 1038-1044.

Hansch, C., and A. Leo (1979) Substituent Constants for Correlation Analysis in Chemistry and Biology, John Wiley \& Sons, NY.

Harter, D.R. (1985) The use and importance of nitroaromatic chemicals in the chemical industry, in: D.E. Rickert (Ed.), Toxicity of Nitroaromatic Compounds, Hemisphere Publishing, Washington, pp. 1-15. 
Klopman, G., D.A. Tonucci, M. Holloway and H.S. Rosenkranz (1984) Relationship between polarographic reduction potential and mutagenicity of nitroarenes, $\mathrm{Mu}$ tation Res., 126, 139-144.

Maron, D.M. and B.N. Ames (1983) Revised methods for the Salmonella mutagenicity test, Mutation Res., 113, 173-215.

Maynard, A.T., L.G. Pedersen, H.S. Posner and J.D. McKinney (1986) An $a b$ initio study of the relationship between nitroarene mutagenicity and electron affinity, Mol. Pharmacol., 29, 629-636.

Mermelstein, R., E.C. McCoy and H.S. Rosenkranz (1985) The mutagenic properties of nitroarenes: structure-activity relationships, in D.E. Rickert (Ed.) Toxicity of Nitroaromatic Compounds, Hemisphere Publishing, Washington, pp. 205-230.

Mullin, C.A., K.A. Rashid and R.O. Mumma (1987) Mutagenic potency of some conjugated nitroaromatic compounds and its relationship to structure, Mutation Res., $188,267-274$.

Richter, F. (Ed.) (1931) Beilstein's Handbuch Der Organischen Chemie, Suppl. 1, Vol. 6, Julius Springer, Berlin, p. 335.

Rickert, D.E. (Ed.) (1985) Toxicity of Nitroaromatic Compounds, Hemisphere Publishing, Washington, $295 \mathrm{pp.}$

Rosenkranz, H.S. and R. Mermelstein (1983) Mutagenicity and genotoxicity of nitroarenes. All nitro-containing chemicals were not created equal, Mutation. Res., 114, 217-267.

Rosenkranz, H.S. and R. Mermelstein (1985) The genotoxicity, metabolism and carcinogenicity of nitrated polycyclic aromatic hydrocarbons, J. Environ. Sci. Health, C3, 221272.

Schiemenz, G.P. and J. Thobe (1966) Aromatic phosphines with second order substituents. III. New variation of the Wittig reaction, Chem. Ber., 99, 2663-2668.
Sinsheimer, J.E., B.H. Hooberman, S.K. Das, M.D. Brezzell and Z. You (1992) The in vivo and in vitro genotoxicity of aromatic amines in relationship to the genotoxicity of benzidine, Mutation Res., 268, 255-264.

Tokiwa, H. and Y. Ohnishi (1986) Mutagenicity and carcinogenicity of nitroarenes and their sources in the environment, CRC Crit. Rev. Toxicol., 17, 23-60.

Topliss, J.G. and R.P. Edwards (1979) Chance factors in studies of quantitative structure-activity relationships, $\mathrm{J}$. Med. Chem., 22, 1238-1244.

Vance, W.A., Y.Y. Wang and H.S. Okamoto (1987) Disubstituted amino-, nitroso-, and nitrofluorenes: a physicochemical basis for structure-activity relationships in Salmonella typhimurium, Environ. Mutagen., 9, 123-141.

Vance, W.A., H.S. Okamoto and Y.Y. Wang (1988) Structural features of nitroaromatics and their reduction products that affect mutagenic potency in the Ames Salmonella assay, in: C.M. King, L.J. Romano and D. Schuetzle (Eds.), Carcinogenic and Mutagenic Responses to Aromatic Amines and Nitroarenes, Elsevier, New York, pp. 291-302.

Veschamber, H. and A. Kergomard (1966) La transmission des effets électroniques dans les trans stilbènes substitués, Bull. Soc. Chim. France, 336-342.

Weast, R.C. and J.G. Grasselli (1989) Handbook of Data on Organic Compounds, 2nd ed., CRC Press, Boca Raton.

You, Z., M.D. Brezzell, S.K. Das, M.C. Espadas-Torre, B.H. Hooberman and J.E. Sinsheimer (1993) ortho-Substituent effects on the in vitro and in vivo genotoxicity of benzidine derivatives, Mutation Res., 319, 19-30.

You, Z., M.D. Brezzell, S.K. Das, B.H. Hooberman and J.E. Sinsheimer (1994) Substituent effects on the in vitro and in vivo genotoxicity of 4-aminobiphenyl and 4-aminostilbene derivatives, Mutation Res., 320, 45-58. 